\title{
MENGUNGKAP STRATEGI PEMASARAN YANG DILAKUKAN OLEH USAHA JASA WARNET ( STUDI KASUS DI MEDIA - NET CAB. CINDE SEMARANG )
}

\author{
Dwi Widi Pratito S.N. \\ Ilham Yudan Ashari Saputra
}

Diterima: Februari 2019, Disetujui: Maret 2019. Dipublikasikan: April 2019

\begin{abstract}
This research is in the background with the era of this modern era and instantaneous, the internet has penetrated into the world of services called internet cafes. Basically, internet cafe is a form of business managed by one group or individual who provides services in the form of internet services by its users. Usually users are charged hourly fees or packages, according to how long they are used.

This research uses qualitative approach, the research location in MEDIA - NET internet cafe located on Jl Cinde Barat 1 Ruko No. 2, Jomblang Village, Candisari District, Jomblang, Candisari, Semarang City, Central Java. Source of data using observation, interviews, and documentation.

The results of this study are: service products offered at this cafe are quite diverse such as student packages, general packages, and night packages that are in great demand by many groups. promotion can be done is to only spread brochures in schools around the place of business and red lights in student soldiers. The place chosen by MEDIA - NET is quite strategic because the chosen place is close to the school and residential areas and most importantly close to the highway.
\end{abstract}

Keywords: MEDIA - NET, Products, Places, Promotions, Prices

\begin{abstract}
ABSTRAK
Penelitian ini di latar belakangi dengan di zaman era modern ini dan serba instan, internet sudah merambah ke dunia bidang jasa yang disebut sebagai warnet. Pada dasarnya, warnet merupakan salah satu bentuk usaha yang dikelola oleh satu kelompok atau individu yang memberikan pelayanan berupa jasa internet oleh penggunanya. Biasanya pengguna dikenakan biaya per jam atau paket, sesuai lama penggunannya.

Penelitian ini menggunakan pemdekatan kualitatif,lokasi penelitian di warnet MEDIA - NET yang terletak di Jl Cinde Barat 1 Ruko No. 2, Kelurahan Jomblang, Kecamatan Candisari, Jomblang, Candisari, Kota Semarang, Jawa Tengah. Sumber data menggunakan observasi,wawancara,dan dokumentasi.

Hasil penelitian ini adalah : produk jasa yang ditawarkan di warnet ini cukup beragam seperti paket pelajar,paket umum,dan paket malam yang sangat diminati oleh banyak kalangan. dapat promosi yang dilakukan adalah hanya menyebar brosur saja di sekolah-sekolah sekitar tempat usaha dan lampu merah di tentara pelajar. Tempat yang dipilih oleh MEDIA - NET cukup strategis karena tempat yang dipilih berdekatan dengan sekolah dan pemukiman warga dan yang terpenting dekat dengan jalan raya.
\end{abstract}

Kata Kunci $\quad$ : MEDIA - NET, Produk,Tempat,Promosi,Harga

\section{PENDAHULUAN}

\section{Latar Belakang}

Selama kurang lebih dua puluh tahun ini dunia mengalami perkembangan yang begitu pesat karena adanya perubahan teknologi. Dulu, banyak sekali hal yang tampak mustahil seperti berkomunikasi langsung dipisahkan dua benua secara face to face, ataupun pengiriman data dengan hanya hitungan detik dianggap hanya dewa yang bisa 
melakukannya, atau kalaupun ada, dengan tingginya harga hanya segelintir orang yang bisa menikmatinya. Sekarang hal-hal mustahil itu sudah dapat dilakukan bahkan dijual dengan harga murah. Dengan adanya perubahan teknologi seperti itu, perpindahan informasi dari ujung dunia yang satu ke ujung dunia yang lain hanya hitungan detik dengan biaya murah bahkan nyaris gratis. Tidak heran banyak orang menyebut era ini sebagai era informasi.

Internet telah membuat revolusi baru dalam dunia komputer dan dunia komunikasi yang tidak pernah diduga sebelumnya. Beberapa Penemuan telegram, telepon, radio, dan komputer merupakan rangkaian kerja ilmiah yang menuntun menuju terciptanya Internet yang lebih terintegrasi dan lebih berkemampuan dari pada alat-alat tersebut. Internet memiliki kemampuan penyiaran ke seluruh dunia, memiliki mekanisme diseminasi informasi, dan sebagai media untuk berkolaborasi dan berinteraksi antara individu dengan komputernya tanpa dibatasi oleh kondisi geografis.

Internet merupakan sebuah contoh paling sukses dari usaha investasi yang tak pernah henti dan komitmen untuk melakukan riset berikut pengembangan infrastruktur teknologi informasi. Dimulai dengan penelitian packet switching (paket pensaklaran), pemerintah, industri dan para civitas academica telah bekerjasama berupaya mengubah dan menciptakan teknologi baru yang menarik ini.

Sudah hampir seperempat abad masyarakat dunia menggunakan Internet. Hingga saat ini Internet sudah digunakan oleh masyarakat dari berbagai usia dan generasi. Hasil penelitian Yahoo dan Taylor Nelson Sofres (TNS) Indonesia tahun 2009 menunjukkan pengakses terbesar di Indonesia adalah mereka yang berusia antara 15-19 tahun. Dari 2.000 responden yang mengikuti survei ini, didapat hasil sebanyak 64 persen adalah anak muda. Masih dari hasil penelitian yang sama, 53 persen usia 15-40 tersebut ternyata mengakses Internet dari warnet. Itu disebabkan oleh mereka mempunyai waktu luang yang lebih banyak dibanding para pekerja (Kompas.com, 20/03/2009).

Di era modern ini dan serba instan, internet sudah merambah ke dunia bidang jasa yang disebut sebagai warnet. Pada dasarnya, warnet merupakan salah satu bentuk usaha yang dikelola oleh satu kelompok atau individu yang memberikan pelayanan berupa jasa internet oleh penggunanya. Biasanya pengguna dikenakan biaya per jam atau paket, sesuai lama penggunannya. 
Pada awal tahun 1990an, usaha warnet masih belum berkembang. Hal ini disebabkan oleh karena pada tahun tersebut, internet belum dikenal oleh masyarakat indonesia. Walaupun pada tahun tersebut internet sudah ada, namun pada saat itu internet masih belum beredar umum. Berbeda dengan kondisi internet pada jaman sekarang yang sangat komersil dan individual di sebagian aktifitasnya terutama yang melibatkan perdagangan di internet. Namun semenjak memasuki milinium baru, perkembangan internet di dunia begitu pesat. Hal itu menyebabkan bertambahnya kebutuhan konsumen akan fasilitas internet, maka usaha warnetpun mulai muncul.

Warnet Media - Net yang bergerak di bidang usaha penyediaan jasa warnet, juga terkena dampak pesatnya kemajuan teknologi tersebut. Hal ini dapat dilihat dari tabel dibawah ini :

\begin{tabular}{|c|c|}
\hline Tahun & Jumlah \\
\hline 2016 & 17.561 \\
\hline 2017 & 19.721 \\
\hline 2018 & 20.324 \\
\hline
\end{tabular}

Data Jumlah Pengunjung Media - Net Semarang

Sumber : Data Media - Net 2 tahun kebelakang

Dari tabel diatas dapat diketahui bahwa Media - NET mengalami peningkatan pengunjung secara signifikan dari tahun ke tahun ke tahun. dan didalam tabel tersebut tidak ada penurunan pelanggan yang begitu signifikan dari tahun $2016-2018$.

Berdasarkan latar belakang di atas maka penulis tertarik membahas permasalahan dalam bisnis warnet dengan judul "mengungkap strategi pemasaran yang dilakukan oleh usaha jasa warnet ( Studi kasus di Media - NET Cab. Cinde Semarang )"

\section{Rumusan Masalah}

Berdasarkan latar belakang diatas, pemilik usaha dari jasa warnet MEDIA - NET ini harus mengetahui bagaimana strategi pengelolaan yang baik dalam mengembangkan usaha ini sehingga bisa maju dan bisa unggul dalam persaingan bisnis yang ketat.Maka masalah penelitian yang akan di teliti adalah bagaimana strategi pemasaran yang dilakukan MEDIA - NET Untuk dapat mengelola usaha ini sehingga bisa memperluas pasarnya. 


\section{Tujuan Penelitian dan Kegunaan Penelitian}

\section{Tujuan Penelitian}

\section{a. Tujuan Umum}

Untuk mengetahui strategi bauran pemasaran pada usaha warnet MEDIA - NET

\section{b. Tujuan Khusus}

1. Untuk mengetahui strategi pemasaran yang diterapkan oleh MEDIA - NET

2. Untuk mengetahui faktor pendukung dan penghambat pada strategi MEDIA NET.

\section{Kegunaan Penelitian}

Manfaat yang diharapkan dari hasil penelitian yang dilakukan adalah sebagai berikut :

\section{a. Bagi Peneliti}

Penelitian ini diharapkan menambah pengetahuan dan wawasan khususnya mengenai pengelolaan dalam menggunakan jasa, serta untuk menyusun skripsi sebagai syarat memperoleh gelar Sarjana Ekonomi di Fakultas Ekonomi, Universitas Semarang.

b. Bagi Instansi Terkait

Penelitian ini diharapkan dapat memberikan masukan berupa saran dan informasi kepada pihak pemilik usaha jsa warnet MEDIA - NET tentang strategi pemasaran dalam mengembangkan usaha ini.

\section{TINJAUAN PUSTAKA}

\section{Wirausaha}

Menurut Peter F. Drucker dalam buku Kasmir ( 2017 : 20 ) menmgatakan bahwa kewiraushaan merupakan kemampuan dalam menciptakan sesuatu yang baru dan berbeda dari yang lainnya.

Sementara itu Zimmer dalam buku Kasmir ( 2017 : 20 ) mengartikan bahwa kewirausahaan sebagai suatu proses penerapan kretivitas dan inovasi dalam memecahkan persolaan dan menemukan peluang untuk memperbaiki kehidupan (Usaha).

Disini penekanan kewirausahaan adalah mengenai proses menciptakan sesuatu yang berbeda, yang memiliki nilai tambah melalui pengorbanan waktu dan tenaga dengan berbagai resiko sosial dan mendapatkan penghargaan akan sesuatu yang 
diperoleh beserta dengan timbulnya kepuasaaan pribadi dari hasil yang diperoleh. Pengertian wirausaha disini menekankan pada setiap orang yang memulai sesuatu bisnis yang baru. Secara sederhana dapat dikatakan bahwa wirausaha adalah orang yang mempunyai kemampuan melihat dan menilai kesempatan atau peluangpeluang bisnis (Sudrajad, 2011:26).

Kesimpulan dari pengertian diatas bahwa kwirausahaan adalah proses seseorang yang ingin mencapai atau menciptakan kekayaan inkremental dan menanggung semua resiko yang dihadapi oleh setiap individu tersebut

\section{Karakteristik Wirausaha}

Menurut para ahli mengatakan karakteristik kewirausahaan dengan konsep yang berbeda-beda.Geoffreyn G. Meredith (1996 : 5-6) dalam buku Suryana,M.Si ( 2006:24 )untuk menjadi wirausahawan, seorang harus memiliki karakteristik sebagai berikut:

1. Percaya diri dan optomis

2. Berorientasi pada tugas dan hasil

3. Berani mengambil risiko dan menyukai tantangan

4. Kepemimpinan

5. Keorisinalan

6. Berorientasi masa depan

Geoffreyn G. Meredith (1996 : 5-6) dalam buku Suryana,M.Si (2006:24)

\section{Karakteristik Wirausaha Di Indonesia}

Banyak cara untuk cara menjadi seorang wirausahawan, antara lain dengan mendirikan bisnis baru ataupun membeli sistem bisnis yang telah ada dan telah berjalan, yaitu dengan sistem bisnis waralaba. Bagi masyarakat yang ingin menjadi pengusaha tetapi belum memiliki pengetahuan dan pengalaman dalam bisnis, waralaba atau franchise merupakan bisnis yang cocok bagi mereka karena tidak perlu membangun bisnis mulai dari nol, sehingga potensi kegagalan dalam memulai usaha sangatlah kecil, hal ini karena sistem tersebut telah teruji dan siap dijalankan oleh pembeli sistem bisnis tersebut (Hapsari, 2008).

\section{STRATEGI PEMASARAN}

Terdapat beberapa macam pengertian strategi dari para ahli. Menurut Marrus dalam Umar (2001:31) strategi didefinisikan sebagai suatu proses penentuan rencana para 
pemimpin puncak yang berfokus pada tujuan jangka panjang organisasi, disertai penyusunan suatu cara atau upaya bagaimana agar tujuan tersebut dapat dicapai. Strategi didefinisikan secara khusus sebagai tindakan yang bersifat incremental (senantiasa meningkat) dan terus-menerus, serta dilakukan berdasarkan sudut pandang tentang apa yang diharapkan oleh para pelanggan di masa depan (Prahalad dalam Umar, 2001:31).

Menurut American Marketing Assosiation dalam Kotler dan Keller (2009:6) yang disitasi oleh (Taufik \& Suprajang, 2015) pemasaran adalah satu fungsi organisasi dan seperangkat proses untuk menciptakan, mengkomunikasikan, dan menyerahkan nilai kepada pelanggan dan mengelola hubungan pelanggan dengan cara yang menguntungkan organisasi dan para pemilik sahamnya.

\section{KOMPONEN STRATEGI PEMASARAN}

Strategi pemasaran memiliki tiga komponen yakni segmentasi, targeting, positioning:

\begin{tabular}{|c|c|c|}
\hline $\begin{array}{l}\text { Segmenting } \\
\text { 1. Mengidentifikasi } \\
\text { variabel } \\
\text { segmentasi dan } \\
\text { segmentasi } \\
\text { pasar. } \\
\text { 2. Mengembangkan } \\
\text { bentuk segmen } \\
\text { yang } \\
\text { mengunt ungkan }\end{array}$ & $\begin{array}{l}\text { Targetting } \\
\text { 3. Mengevaluasi } \\
\text { daya tarik } \\
\text { masing-masing } \\
\text { segmen. } \\
\text { 4. memilih segmen } \\
\text { yang } \\
\text { mengunt ungkan }\end{array}$ & $\begin{array}{l}\text { Positioning } \\
\text { 5. mengident ifikasi } \\
\text { positioning yang } \\
\text { mungkin unt uk } \\
\text { masing-masing } \\
\text { segmen. } \\
\text { 6. Memilih dan } \\
\text { mengkomunikasi } \\
\text { kan positioning } \\
\text { yang terpilih. }\end{array}$ \\
\hline
\end{tabular}

Gambar 2.1.5 Komponen Strategi Pemasaran

Dari paparan gambar 2 dapat kita ketahui bahwa langkah pertama ialah segmentation dengan cara membagi pasar dalam variabel yang berbeda menurut kebutuhan, karakteristik, dan perilaku kemudian mengembangkan bentuk segmen yang dinilai menguntungkan perusahaan. Langkah kedua targeting ialah proses mengevaluasi daya tarik masing masing segmen pasar dan memilih satu atau lebih jumlah segmen 
yang dimasuki. Langkah positioning yang efektif dimulai dengan diferensiasi yang benar-benar mendiferensiasikan penawaran pasar perusahaan sehingga perusahaan dapat memberikan nilai lebih kepada konsumen.Sedangkan positioningadalah pengaturan produk untuk menduduki tempat yang jelas, berbeda, dan diinginkan relatif terhadap produk pesaing dalam pikiran konsumen sasaran.

\section{Marketing Mix (Bauran pemasaran)}

Setelah memutuskan seluruh strategi pemasarannya, perusahaan siap untuk mulai merencanakan rincian bauran pemasaran, salah satu konsep utama dalam pemasaran modern. Bauran pemasaran (marketing mix) adalah kumpulan alat pemasaran taktis terkendali yang dipadukan perusahaan untuk menghasilkan respons yang diinginkannya di pasar sasaran. Bauran pemasaran terdiri dari empat variabel yang disebut "4P": Produc(produk), Price (harga), Place (tempat), Promotion (promosi).

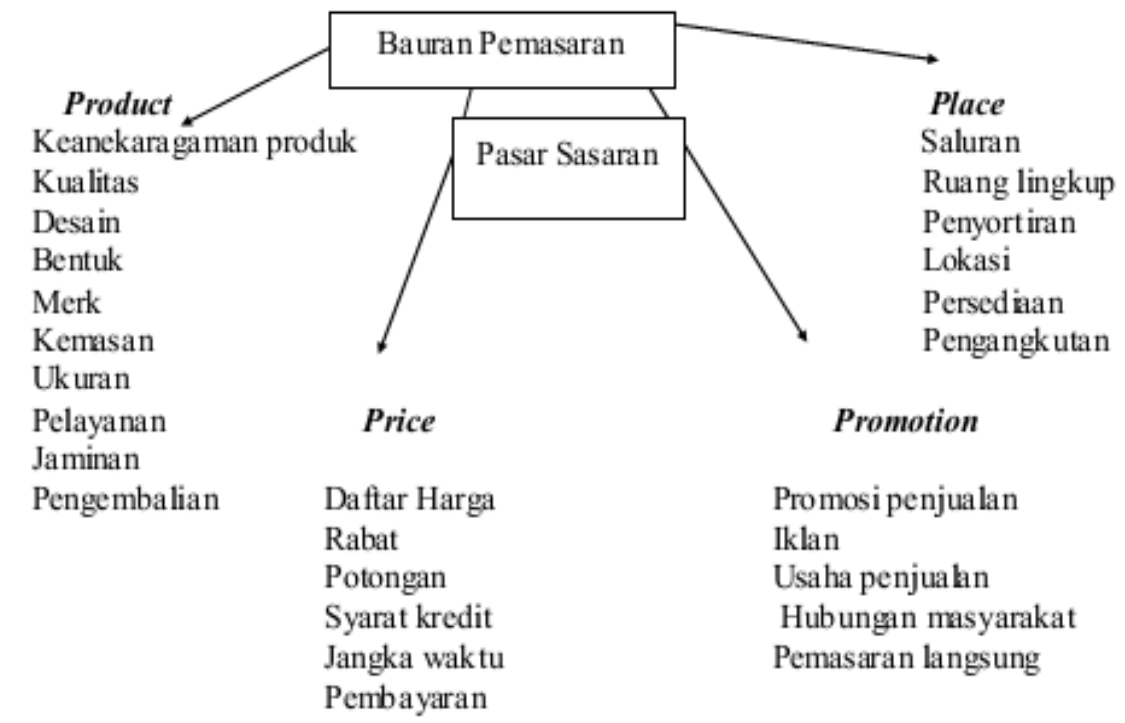

Gambar 2.1.6 Bagan Marketing Mix

\section{Produc (Produk)}

Menurut Philip Kotler dalam buku Dr. Kasmir ( 2017 : 188 ) produk adalah sesuatu yang dapat ditawarkan ke pasar untuk mendapatkan perhatian untuk dibeli, digunakan, atau dikonsumsi, sehingga dapat memenuhi keinginan dan kebutuhan.

\section{Price (Harga)}

Harga merupakan satu satunya unsur bauran pemasaran yang memberikanpemasukan atau pendapatan bagi perusahaan, sedangkan ketiga unsur 
lainnya (produk, tempat,dan promosi) menyebabkan timbulnya biaya/pengeluaran (Tjiptono, 2008 : 151). Menurut Kotler dan Armstrong (2008 : 63) harga adalah jumlah uang yang harus dibayarkan pelanggan untuk memperoleh produk.

\section{Place (Tempat)}

Tempat atau saluran distribusi adalah serangkaian organisasi yang sering tergantung yang terlibat dalam proses untuk menjadikan suatu produk atau jasa siap untuk digunakan atau dikonsumsi.

Saluran distribusi dapat di definisikan sebagai himpunan perusahaan dan perorangan yang mengambil alih hak atau membantu dalam pengalihan hak atas barang atau jasa tertentu selama barang atau jasa tersebut berpindah dari produsen ke konsumen (Kotler, 2005).Saluran distribusi didasarkan pada tujuan perusahaan yang ingin dicapai, ciri-ciri pasar yang dijadikan sasaran, dan karakteristik produk yang ditawarkan.

\section{Promotion (Promosi)}

Difinisi promosi ialah berbagai kegiatan yang dilakukan oleh produsen untuk mengomunikasikan manfaat dari produknya, membujuk, dan mengingatkan para konsumen sasaran agar membeli produk tersebut (Kotler,2005).

\section{Metode Penelitian}

\section{Desain Penelitian}

Sesuai dengan permasalahan dan uraian pada latar belakang, penelitian ini dilakukan dengan menggunakan jenis penelitian kualitatif. Jenis desain penelitian adalah deskriptif. Menurut Meleong 2002 dalam Hermawanto (2014:1292) mengemukakan bahwa penelitian kualitatif yaitu suatu penelitian yang bersifat ilmiah, yang tergantung pada suatu pengamatan pada manusia dalam kawasannya sendiri yang berhubungan dengan orang-orang, latar dan perilaku secara holistik (utuh). Penelitian kualitatif dengan desain deskripstif yang merupakan penelitian terhadap fenomena tertentu yang diperoleh penelitian dari subjek berupa kelompok atau perspektif lain menurut Oktariyanda, et al. (2013). Desain deskripstif ini menjawab atas pernyataan-pernyataan tentang siapa,apa, kapan, dimana dan bagiamana keterkaitan dengan penelitian. Digunakan untuk memperoleh informasi mengenai status fenomena variabel atau kondisi situasi. 
Penelitian ini digunakan untuk mengetahui strategi pemasaran pada usaha jasa warnet MEDIA - NET yang terletak di jl. Cinde Barat 1 Ruko No.2 kelurahan Jomblang, Kecamatan Candisari, Semarang Selatan. Sehingga penelitian ini tergolong pada tipe penelitian kualitatif dengan jenis desain deskriptif. Penelitian ini memberikan gambaran atau penjelasan tentang aspek-aspek yang rentan dari fenomena yang diamati, serta menggambarkan keadaan yang sedang berjalan pada saat penelitian dan memeriksa fakta tertulis atau lisan atau perilaku yang diamati.

\section{Tempat dan Waktu Penelitian}

Penelitian ini dilakukan di warnet MEDIA - NET yang terletak di jl. Cinde Barat 1 Ruko No.2 kelurahan Jomblang, Kecamatan Candisari, Semarang Selatan. Waktu pelaksanaan penelitian pada 20 November 2018 sampai 10 Desember 2018.

\section{Objek Penelitian}

Menurut Sugyono (2016:19) objek penelitian adalah sasaran ilmiah untuk mendapatkan data dengan tujuan dan kegunaan tertentu tentang suatu hal yang objektif, valid dan reailble tentang suatu hal (variabel tertentu).

Dalam penelitian yang dilakukan, objek penelitian yang diteliti yaitu strategi pemasaran yang terkait dengan 4P (Product, Price, Promotion, Place) dan faktor pendukung dan penghambat strategi pemasaran. Sedangkan yang dijadikan sebagai subjek dalam penelitian ini adalah usaha jasa warnet MEDIA - NET yang terletak di jl. Cinde Barat 1 Ruko No.2 kelurahan Jomblang, Kecamatan Candisari, Semarang Selatan Jenis Data Penelitian

Berdasarkan permasalahan diatas maka jenis data yang digunakan adalah jenis data primer dan sekunder.

\section{Data Primer}

Data primer merupakan sumber data yang langsung memberikan data kepada pengepul data (Sugiyono, 2016: 137). Dalam penelitian ini penulis mendapatkan data secara langsung di usaha bidang jasa warnet MEDIA - NET dan hasil dari semua ini adalah hasil data yang diambil dengan cara wawancara kepada informan yaitu pelaku usaha, karyawan / Operator serta Kostumer MEDIA - NET, untuk mendapatkan data tentang strategi pemasaran yang diterapkan MEDIA - NET. 


\section{Data Sekunder}

Data Sekunder, teknik pengumpulan data yang dilakukan dengan mempelajari buku-buku referensi, laporan-laporan, jurnal-jurnal dan media lainnya yang berkaitan dengan pengukuran kualitas pelayanan. Menurut Sugiyono (2009:402) data sekunder adalah sumber data yang tidak langsung memberikan data kepada pengumpul data, dan data sekunder ini merupakan data yang sifatnya mendukung keperluan data primer seperti buku-buku, literatur dan bacaan yang berkaitan dengan pelaksanaan.

\section{Prosedur dan Pengumpulan Data}

Teknik perolehan data dalam penelitian ini menggunakan teknik yang dikemukakan oleh Sugiyono (2016: 225) yang terdiri dari wawancara, observasi, dokumentasi dan triagulasi atau gabungan.

\section{Wawancara}

Menurut Sugiyono (2016:231) wawancara adalah merupakan pertemuan dua orang untuk bertukar informasi dan ide melalui tanya jawab, sehingga dapat dikonstruksikan makna dalam suatu topik tertentu.

\section{Observasi}

Disamping wawancara, penelitian ini juga melakukan metode observasi. Menurut Marshall (1995) dalam Sugiyono (2015:309) menyatakan bahwa "through observation, the researcher learn about behavior and the meaning attached to those behavior". Melalui observasi, peneliti belajar tentang perilaku dan makna dari perilaku tersebut. Observasi adalah suatu cara yang digunakan untuk memperoleh data atau informasi melalui panca indera yang dilakukan secara sistematik yaitu dengan cara mengadakan pengamatan langsung maupun tidak langsung agar dapat memperoleh kayakinan atas data yang didapat melalui kenyataan yang ada menurut Oktariyanda, et al (2013). 


\section{Gambar 3.2}

\section{Triangulasi “Teknik" Pengumpulan Data}

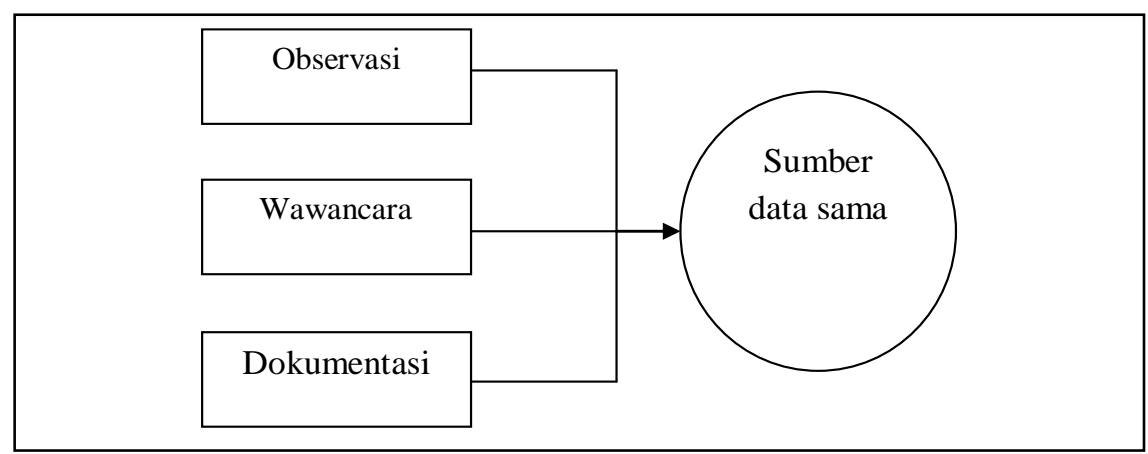

Sumber : Sugiyono (2015:328)

\section{Pemilihan Informan}

Informan dalam penelitian adalah orang atau pelaku yang benar-benar tahu dan menguasai masalah, serta terlibat lansung dengan masalah penelitian.Dengan mengunakan metode penelitian kualitatif, maka sangat erat kaitannya dengan faktor-faktor kontekstual, jadi dalam hal ini sampling dijaring sebanyak mungkin informasi dari berbagai sumber. Maksud kedua dari informan adalah untuk mengali informasi yang menjadi dasar dan rancangan teori yang dibangun.

Tabel 3.3

Nama Informan dan Waktu Wawancara

\begin{tabular}{|c|l|l|l|}
\hline $\begin{array}{c}\text { No } \\
.\end{array}$ & \multicolumn{1}{|c|}{ Nama } & \multicolumn{1}{|c|}{ Keterangan } & Waktu \\
\hline 1 & Bp. Purnomo & $\begin{array}{l}\text { Beliauadalahpemilikdari MEDIA - NET ini, } \\
\text { Beliauusia 38 tahun. Beliautinggal di daerah Tegal } \\
\text { Sari dekat Kawi }\end{array}$ & 20 November 2018 \\
\hline 2 & $\begin{array}{l}\text { MbakAnggi } \\
\text { Renita }\end{array}$ & $\begin{array}{l}\text { Mbakangginiadalahsalahsatu operator yang ada } \\
\text { di MEDIA - NET ini, diaberusia 23 } \\
\text { tahundanberstatussebagaimahasiswa di } \\
\text { universitasswasta yang ada di Semarang }\end{array}$ & 28 November 2018 \\
\hline 3 & $\begin{array}{l}\text { Mas Rama } \\
\text { Aditya }\end{array}$ & $\begin{array}{l}\text { Mas Rama } \\
\text { iniadalahsebagaiCustomeryangmenggunakanlaya } \\
\text { nan internet di MEDIA - NET. Diabekerja di } \\
\text { Traveloka Semarang }\end{array}$ & 10 Desember 2018 \\
\hline
\end{tabular}

Sumber : Dari Hasilwawancara 


\section{Teknis Analisis Data}

Dalam melaksanakan penelitian ini, peneliti melakukan teknik analisis data dengan model Miles dan Huberman (1984) dalam Sugiyono (2015:334) mengemukakan bahwa aktivitas dalam analisis kualitatif dilakukan secara interaktif dan berlangsung secara terus menerus sampai tuntas, sehingga datanya jenuh. Aktivitas dalam analisis data ini yaitu :

\section{Data Reduction (Reduksi Data)}

Data yang diperoleh dari lapangan jumlahnya cukup banyak, untuk itu perlu dicatat secara teliti dan rinci.Mereduksi data berarti merangkum, memilih hal-hal yang pokok, memfokuskan pada hal-hal yang penting, lalu dicari tema dan polanya menurut Sugiyono (2015:336).Data-data direduksi dengan menguji keabsahannya dan keterkaitannya dengan topik penelitian serta landasan teori yang digunakan. Data yang telah direduksi akan memberikan gambaran yang jelas, dan mempermudah peneliti untuk melakukan pengumpulan data selanjutnya dan mencarinya bila diperlukan.

\section{Data Display (Menyajikan Data)}

Setelah data di reduksi, maka langkah selanjutnya adalah menyajikan data.Dalam penyajian data bisa dilakukan dalam bentuk uraian singkat, bagan, hubungan antar kategori, flowchart dan sejenisnya. Cara yang paling sering digunakan untuk menyajikan data dalam penelitian kualitatif adalah dengan teks yang bersifat naratif.

\section{Penarikan / Verifikasi Kesimpulan}

Kesimpulan berasal dari pengumpulan data peneliti secara kualitatif dan mulai memutuskan apakah makna sesuatu, mencatat keteraturan, pola-pola penjelasan, konfirgurasi yang mungkin, alur kasual dan porposisi-porposisi. Setelah data yang disajikan tersebut dibahas secara rinci, maka selanjutnya data tersebut diambil kesimpulannya. Kesimpulan digunakan sebagai jawaban dari permasalahan yang diteliti.

\section{HASIL PENELITIAN DAN PEMBAHASAN}

\section{Gambaran Umum Obyek Penelitian}

Pada dasarnya jiwa dan sikap kewirausahaan tidak hanya dimiliki oleh usahawan, namun juga oleh setiap orang yang berfikir kreatif dan bertindak inovatif misalnya petani, karyawan, pegawai pemerintah, mahasiswa, guru, pimpinan proyek, dan lain 
sebagainya. Memang pada awalnya kewirausahaan dijumpai dalam dunia bisnis, akan tetapi akhir-akhir ini berkembang dalam berbagai aspek kehidupan, bahkan sering digunakan sebagai salah satu persyaratan untuk menjadi pemimpin suatu perusahaan.

Kewirausahaan (entrepreneurship) adalah kemampuan kreatif dan inovatif yang dijadikan dasar, kiat, dan sumber daya untuk mencari peluang menuju sukses. Menurut Peter F. Drucker dalam buku Dr.Kasmir ( 2017 : 20 ) menmgatakan bahwa kewiraushaan merupakan kemampuan dalam menciptakan sesuatu yang baru dan berbeda dari yang lainnya. Pada zaman era modern ini banyak sekali peluang usaha yang ada seperti halnya usaha jasa warnet.

Beberapateknologiakses Internet yang sekarang diberitakan berbiaya murah pun, jika diperhatikan, ternya tatetap mahal. Harga perangkat komputer, baik perangkat keras maupun lunak, masih tidak terjangkau oleh sebagian besar masyarakat kita sehingga kebutuhan akan warnet akan selalu ada.

Semakin maraknya penggunaan Internet membuat para pebisnisatau investor melirik peluang ini sebagai usaha yang menjanjikan. Tak hanya konsultan atau pebisnis spesialis, pengusaha tanggung yang hanya memiliki modal pas - pasan pun dapat membangun bisnis ini dengan segenap usaha penekanan terhadap biaya. Seperti yang kita ketahui bahwa investasi awal pada proyek yang berhubungan dengan IT (Information Technology) adalah investasi yang sangat besar. Investasi awal yang ditanam pada pembangunan warnet ini meliputi pembuatan jaringan serta instalasi perangkat keras dan perangkat lunak. Tidak ketinggalan izin usaha yang merupakan poin penting.

Warnet MEDIA - NET adalah salah satu jenis usaha yang ada dari beberapa usaha-usaha yang telah ada sebelumnya, usaha ini didirikan oleh Bp. Purnomo yang berdiri di Jl Cinde Barat 1 Ruko No. 2, Kelurahan Jomblang, Kecamatan Candisari, Jomblang, Candisari, Kota Semarang, Jawa Tengah. Usaha ini bergerak dibidang jasa internet dan sudah berdiri sejak tahun 2014 lalu hingga sekarang.

Warnet ini memiliki berbagai jenis produk / jasa yang ditawarkan mulai dari paket promo ,paket jam , paket malam, jasa pengetikan , jasa pencarian film , pencarian lagu, pencarian tugas, dan masih banyak lagi. Warnet ini memiliki 8 karyawan yang masing masing terbagi menjadi 2 grub kecil yaitu grub pagi - malam ( $06.00-09.00$ ), dan grub malam - pagi ( 09.00 - 06.00 ) didalam grub ini terbagi beberapa bagian yaitu 
wanita dan pria, tugas jaga dari merekapun berbeda seperti Operator wanita di tugaskan di sift pagi dan sedangkan untuk pria ditugaskan di sift malam.

Berikut daftar-daftar jasa yang paling di minati oleh pengunjung :

\begin{tabular}{|l|l|l|}
\hline No. & Daftar - daftarproduk & Harga \\
\hline 1. & Paket 2 jam & Rp. 11.000 \\
\hline 2. & Paket 3 jam & Rp. 14. 000 \\
\hline 3. & Paket 5 jam & Rp. 19.000 \\
\hline 4. & Paketmalam 10 Jam & Rp. 23.000 \\
\hline 5. & Jasa download film & Rp. 5000 / film \\
\hline 6. & Pengetikan & Rp. 2000 ((Max 3 Lembar) \\
\hline 7. & Jasa download lagu & Rp. 3000 / 10 Lagu \\
\hline
\end{tabular}

Sumber :Hasilwawancaraterdahulu di MEDIA - NET

\section{Profil Informan Kunci}

Penelitian ini telah melakukan observasi untuk menentukan informan yang sesuai dengan kriteria yang telah ditentukan sebelumnya. Informan yang telah diambil berjumlah 4 orang, sedangkan informan kunci yaitu pemilik dari usaha jasa warnet ini dalam melaukan pemasaran produknya. Informan kunci adalah infrman yang meberikan penjelasan secara langsung dan rinci terhadap strategi bauran pemasaran yang dilakukan oleh MEDIA - NET.

\section{GambaranPenelitian}

Dalam pemenuhan kebutuhan sehari-hari kita dituntut untuk mendapatkan pengahasilan, salah satunya dengan usaha sendiri atau membuat usaha keluarga, seperti yang dilakukan oleh Bp. Purnomo, awal beliau membangun usaha ini adalah dulu beliau pernah menjadi operator di salah satu warnet di Semarang, lalu beliau berinisiatif untuk membangun usaha warnet ini sendiri. Dengan merintis secara perlahan lahan beliau mampu menyewa sebuah ruko yang ada didaerah cinde, diruko ini beliau membangun usaha kecil yaitu warnet.

\section{Ringkasan Temuan Deskripsi Hasil Peneltian}

\section{Implementasi Bauran Pemasaran Pada Usaha Jasa Warnet MEDIA - NET}

Untuk mengetahui implementasi bauran pemasaran yang dilakukan oleh usaha bidang jasa warnet ini sesungguhnya dilakukan wawancara secara mendalam dengan informan yang jelas dan akurat tentang kondisi yang sesungguhnya. Selain wawancara 
mendalam juga dilakukan pengamatan langsung dan terjun ke lapangan. Untuk mengukur implementasi bauran pemasaran yaitu produk, harga, promosi, tempat secara kualitatif dalam penelitian ini, maka diajukan beberapa pertanyaan dalam wawancara denan informan.

\section{Pembahasan}

berdasarkan hasil penelitian yang diperoleh dari wawancara dengan informan peneliti memperoleh 3 variabel yaitu :

\section{Bauran Produk}

Hasil dari wawancara ini bisa dilihat banyaknya kategori yang diambil utuk mengambil kesimpulan bahwa bauran product ( produk ) adalah salah satu variabel yan mendasari informan megungkapkan bahwa usaha jasa warnet MEDIA - NET ini layak menjadi jasa warnet dan kompeten dalam membangun usaha ini. Pengertian product ( produk ) menururt kotler \& Amstrong (2001 : 346) adalah segala sesuatu yang dapat ditawarkan kepasar untuk mendpatkan perhatian, dibeli, digunakan atau dikonsumsi yang dapat memuaskan keinginan atau kebutuhan.

\section{Bauran Harga}

Harga merupakan satu satunya marketing mix yang memberikan pemasukan atau pendapatan bagi usaha, nominal uang yang telah ditentukan oleh pemilik usaha untuk menual produk jasa yang ditawarkan kepada konsumen. Penempatan harga dipengaruhi oleh faktor internal dan eksternal. Faktor internal tersebut meliputi tuuan usaha, strategi bauran pemasaran, dan biaya yang dikeluarkan untuk membangun usaha tersebut. Faktor ekstrenal : pasar, persaingan dan unsur lngkungan lainnya. Untuk mencapai tujuan esaranya, penjual atau pemilik saha harus pintar menempatkan atau menerapkan harga yang diberikan kepada pengunjung.

\section{Promosi}

Dari hasil wawancara yang saya dapat promosi yang dilakukan adalah hanya menyebar brosur saja di sekolah-sekolah sekitar tempat usaha dan lampu merah di tentara pelajar. Dalam menyebar brosur semua karyawan dan manajer ikut serta menyebar brosur tersebut, tanpa rasa alu mereka menyebarkannya dengan penuh semngat dan senang. Didalam brosur terebut dituliskan gratis 1 jam, untuk mendapatkan gratis 1 jam pengunjung wajib membawa brosur terebut dan diberikan kepada pihak operator dari MEDIA - NET tersebut. Setelah membrikan brosur tersebut pengunjung 
aan menapatkan free 1 jam utuk bermain di warnet tersebut tanpa dipungut biaya apapun dan promosi ini berlaku untuk selamanya dan tanpa ada batasannya.

\section{Bauran Tempat}

Tempat atau saluran distribusi adalah serangkaian organisasi yang sering tergantug yang terlibat dalam proses untuk menjadikan suatu prodak atau jasa siap untuk digunakan atau di konsumsi. Saluran distribusi dapat didefisinikan sebagai himpunan perusahaan dan perorangan yang mengambil alih hak atau membantu dalam pengalihan hak atau barang atau jasa tertentu selama barang atau jasa tersebut berpindah dari produsen ke konsumen ( kotler, 2005 ).

Tempat yang dipilih oleh MEDIA - NET cukup strategis karena tempat yang dipilih berdekatan dengan sekolah dan pemukiman warga dan yang terpenting dekat dengan jalan raya. Dikarenakan tepat ini begitu menguntungkan bagi pemilik usaha karena yang begitu cukup strategis. Dengan menyewa ruko yang begitu strategis banyak sekali pengunjung yang terbantu dengan adanya warnet ini seperti halnya yang tidak memiliki komputer atau aptop mereka bisa datang ke warnet ini untuk menggunakan jasa ini.

\section{Faktor Penghambat}

segala sesuatu didunia berjalan seimbang ( saling melengkapi ), ada pria pasti ada perempuan, ada siang pasti ada malam, begitupun dalam hal berwrausaha ada faktor pendukung dan faktor penghambat, yang menjadi faktor penghambat berwirausaha dalam ( Agus gunawan, 2009: 6 ) yait : ( 1 ) tidak adanya dana atau modal ( 2 ) sifat kepemimpinan ( 3 ) pengalaman ( 4 ) lokasi.

Faktor penghambat yang dihadapi oleh usaha warnet ini adalah di faktor pesaing dan brosur dikarenakan di daerah tersebut ada pesaing yang membuka jenis usaha yang sama. Kurangnya promosi yang digunakan dan harga per-jamnya yang begitu mahal untuk kalangan mahasiswa atau anak sekolah. Dalam segi jasa pun juga terbatas di bagian operator dan komputer milik operator yang hanya berjumlah 1 saja dan mereka begitu kesusahaan saat banyak pengunjung yang ingin meminta tolong untuk mencarikan tugas atau meminta bantuan untuk mencarikan sesuatu yang dibutuhkan konsumen. 


\section{Faktor Pendukung Strategi Pemasaran}

Wirausaha adalah kemampuan seseorang untuk melihat peluang pasar dan mampu memanfaatkannya dengan menghasilkan sutau barang atau jasa. Keampuan yang didapatkan seseorang tersebut untuk melakukan wirausaha. Adapun aktor pendukung pelaku usaha dalam menerapkan strategi pemasaran yang berkaitan dengan 4P ( Price, product, promotion, and place )

pada usaha jasa warnet MEDIA - NET faktor pendukungnya adalah diberbagai faktor yaitu mulai dari tempat harga promosi dan produk jasa yang ditawarkan. Seperti halnya di faktor harga, warnet ini mematok harga yang cukup mahal yaitu 7000/jam tetapi dengan adanya inovasi yaitu dengan ditambahkannya paket paket tertentu biaya yang dikeluarkan oleh pelanggan tidak begitu mahal. Dan paketan ini pun ditunjang dengan fasilitas koneksi internet yang begitu lancar dan tidak ada hambatan.

\section{Kesimpulan Dan Saran}

\section{Kesimpulan}

Berdasarkan penelitian yag sudah dilakukan di MEDIA - NET dan pembahasan di bab 4, dapat disimpulkan bahwa strategi sukses yang mereka gunakan adalah dengan :

1) Menggunakan harga paket yang lebih murah

2) Dengan menambah fiur-fitur yang ada di komputer

3) Penempatan warnet yang cukup strategis

4) Koneksi internet yang cukup memadai

5) Pelayanan yang ramah

6) Tempat yang begitu nyaman

\subsection{Saran}

Berdasarkan kesimpulan diatas dankenyataan yang terjadi dilapangan, maka munculbeberpa saran sebagai berikut :

1) MEDIA - NET sebaiknya membuka promosi di media sosial karena itu lebih efektif

2) Ditambahkan lagi PC yag ada

3) Ditambah juga kecepatan internet supaya memadai

4) Parkiran motor yang sedikit diperluas 
Majalah Ilmiah Solusi

Vol. 17, No. 2 April 2019

ISSN : 1412-5331

5) Di bagian Operator diberi komputer lagi utuk membantu pengunjung yang ingin diarikan tugasnya 